\title{
A Constitutional Defense of the Electoral College and the Election of the American President
}

\author{
Timothy S. Boylan* \\ Department of Political Science, Winthrop University, Rock Hill, SC 29733, USA
}

\begin{abstract}
As the year 2000 American presidential election came to its conclusion, the Electoral College once again found itself under attack by critics, academics, and politicians. It was criticized as being archaic, flawed, and undemocratic. Calls for its abolition pointed to the principle of "one person, one vote" that had transformed contemporary political participation in the United States over the last century. However, calls for a system of presidential selection based on a pure form of popular democracy can lead to unintended and undemocratic outcomes. By examining the Electoral College in its constitutional as well as its political context this study finds that the Electoral College, rather than subverting democracy, preserves it in ways that are both enduring and significant. Those who suggest amending the Constitution need to confront the many negative consequences of jettisoning the present system of American presidential selection.
\end{abstract}

\section{INTRODUCTION}

This year's presidential race in the United States promises to be close. The possibility of another photo-finish election continues to elicit interest, concern, and dismay. In 2000 , for the first time in more than one hundred years, one candidate won the popular vote and lost the election. Some placed blame on the success of Ralph Nader, a third party candidate. Nader garnered $3 \%$ of the vote, and likely siphoned off enough votes from incumbent Vice-President Al Gore to tip the result in Texas Governor George W. Bush's favor. However, there was another culprit: the Electoral College, the uniquely American system of selecting a president. On the first day of Senate business following the Supreme Court's Bush v. Gore decision, Senator Richard Durbin was on his feet offering a constitutional amendment to abolish the Electoral College. Senator-elect Hillary Clinton condemned the Electoral College in one of her first public communications. The weeks following the final determination of the election saw numerous condemnations of the Electoral College as an anti-democratic instrument. It was called flawed, archaic, and un-American. In an age of "one person, one vote", it had betrayed the $20^{\text {th }}$ Century's progress toward an inclusive, robust, and responsive democracy. In short, it had to go. This issue has simmered for the last eight years. The 2004 election came close to witnessing another complicated finish, ${ }^{1}$ and a fresh set of proposals to abolish or amend the Electoral College's provisions have appeared in both popular and scholarly publications.

*Address correspondence to this author at the Department of Political Science, Winthrop University, Rock Hill, SC 29733, USA;

Tel: (803) 323-4664; E-mail: boylant@winthrop.edu

${ }^{1}$ Here I refer to the vote in Ohio, which could have given Democratic candidate John Kerry the election. Incumbent President Bush carried the state by 130,000 votes, out of 5,500,000 cast. Had Kerry won Ohio, he would have carried the Electoral College and become president, despite the fact that Bush received three million more votes than Kerry nationwide: a far larger number and percentage than candidate Al Gore's national vote total in 2000
This paper asserts that there are reasons why the Electoral College not just survives, but remains relatively unscathed even after an election that did not award the presidency to the majority vote-getter. The Electoral College persists because in the whole it preserves rather than subverts democracy. Close elections and those with an active third party presence may see a result like that of 2000. But, in ways both significant and enduring, the Electoral College provides a structure for fair, democratic and acceptable presidential selection.

With the recent focus on political outcomes, it can sometimes be forgotten that any change in the Electoral College must come through constitutional amendment. The process of presidential selection takes up a significant part of Article II. As a result, any assessment of the College must take into account the constitutional text, and the main ways by which constitutional texts are construed (Bobbitt, 1982). If the Electoral College is to be altered or abolished, it must make constitutional as well as political sense. The debate over the Electoral College can therefore be framed as questions that confront constitutional as well as political realities.

- Has the Electoral College so far departed from its original purposes and intent that it is no longer valid?

- Do federalism and the federal principle conflict with democracy?

- Does the institution of the Electoral College, (as a product and reflection of federalism), hold the potential for undemocratic, and thus illegitimate, outcomes?

As each of these questions is addressed, a summary question can be posed: as American political and constitutional understandings have evolved over 200 years, and as the Constitution itself has been amended to assure more democratic processes, has the Electoral College become "unconstitutional?" This paper will examine three key aspects of constitutional debate: the intent behind the 
language of Article II of the US Constitution, the overall constitutional structure within which the Electoral College operates, and the concept of legitimacy in a democracy. As we look forward to the 2008 elections, and as the questions involving elections and democracy re-emerge, this study attempts to point the discussion toward the key importance of the interconnected legal, theoretical and practical understandings of the debate.

\section{THE TEXT: CREATING THE ELECTORAL COL- LEGE}

A brief review of the creation of the Electoral College is needed at the outset. The College reflects the federal structure created in the Constitution of the United States. Electoral votes are apportioned according to the number of representatives and senators assigned to each state. As a reflection of the size and distribution of the national legislature, it has grown with the addition of new states to the union and changed every ten years with the post-census reapportionment of seats in the House of Representatives (Constitution of the United States, Article 1, Section 3).

The debates surrounding the crafting and final approval of the proposed Constitution during the summer of 1787 revolved around workable compromises. Varied state, economic and ideological interests were represented in Philadelphia, and few walked away with exactly what they wanted. John Roche has persuasively argued that the mindset of the constitutional convention centered on operating "with great delicacy and skill in a political cosmos full of enemies to achieve the one definitive goal-popular approbation" (Roche, 1961, 799). Compromise over the nature of representation led to a bi-cameral legislative branch. Compromises over regional and economic interests (and the intractable problem of slavery) led to a cluster of compromises over treaties, taxation, and commerce. Near the end of the convention, the delegates took up the matter of the newly proposed executive, and the mode of election for this office.

The creation of the Electoral College represented a philosophical and strategic compromise that was designed to accommodate two important needs: conformity to and consistency with a republican form of government, and protection of the executive's independence ${ }^{2}$ James Madison described a republic as,

(a) government which derives all of its powers directly or indirectly from the great body of the people; and is administered by persons holding their offices during pleasure, for a limited period, or during good behavior. It is essential to such a government that it be derived from the great body of society, not from an inconsiderable proportion or a favored class of it... It is sufficient for such a government that the persons administering it be appointed, either directly or indirectly, by the people; and that they hold their appointments by either of the tenures just specified [emphasis in original] (Madison, Hamilton \& Jay, 1961, 240-246)'.

\footnotetext{
${ }^{2}$ Note that these are not the only two areas of compromise. Both Edwards $(2004,87)$ and Amar \& Amar $(2004,58)$ remind us that the Electoral College also reflected a compromise over slavery and voting power, as population-- rather than eligible voters or voter turnout-- determined electoral vote allocation. This adaptation was designed to benefit the southern, slave-holding states.
}

A republican form of government was both defined and ensured by representatives responsible and accountable to the people through frequent elections. Further, the newly proposed Executive would need to remain separate from and not beholden to the other branches of government. Such independence would enable the president to act with energy and vigor - key qualities for effective leadership (Hamilton in Federalist 70. Madison, Hamilton \& Jay, 1961, 423-431)

Two methods of choosing the executive had been originally proposed at the constitutional convention: selection by the legislature and election by the voters. Each had its shortcomings. Legislative selection would likely threaten the independence of the office. The concern was that a president would not be able to establish a separate base of power or act as a check upon legislative power if election depended on the president's popularity with Congress. Popular election did not fare much better. The Framers believed it to be both undesirable and impractical, as the large size of the country and inefficient communications system would hamper a national campaign. Further, the Framers distrusted regional and local impulses that might lead to candidacies based more on popularity and sectionalism than on expertise and ability. Surveying these late summer compromises, Peirce and Longley conclude, "[t]he most basic reason for the invention of the electoral college was that the convention was deadlocked on simpler schemes like direct election and choice by Congress. It devised a system that could be "sold" in the immediate context of 1787” (Peirce \& Longley, 1981, 30).

The Electoral College was the second choice of the majority of the delegates. As a compromise between legislative selection and popular election, presidential electors were to be selected by the states by a process that would be determined by the state legislatures. In this regard, the U.S. Constitution reads:

'Each state shall appoint, in such Manner as the Legislature thereof May direct, a Number of Electors, equal to the whole Number of Senators and Representatives to which State may be entitled in the Congress (Constitution of the United States, Article II, Section 1, Clause 2, 3)'.

There was to be no overlap between Congress and the electors; electors could not be drawn from those holding governmental positions. The separate nature of the College helped to guarantee the independence of the electors.

The mechanisms of the Electoral College also blended participation by and accountability to both the people and the states, the philosophical strands that led to the Connecticut Compromise. It allowed state legislatures to establish the procedures for choosing electors, but if the electoral vote tally did not yield a winner-with a clear majority of the available electoral votes - the resolution of the election shifted to the House of Representatives. In the initial voting larger states would have an advantage, as the electoral awards for each state were in proportion to it's population. However, an election that moved to the House of Representatives provided the smaller states with an equal voice, and reinforced the principle of equal representation for each of the states. The key Article II provision here is that "But in choosing the President, the Votes shall be taken by 
States, the Representation from each State having one Vote." James Madison uses the mechanisms of the Electoral College in his defense of federalism in Federalist 39. The election of the president, the process of ratifying the Constitution and the amendment process all reflect a federal act, where the people make their will known as members of sovereign states. Many contemporary defenses of the Electoral College are grounded in Madison's “compound ratio," reflecting the partly equal, partly unequal form of representation in Congress and participation by the people. In the general election, the people's will would hold sway, but within the confines of the state. In an election that moved to the House, the states would take center stage, but would vote in the chamber of Congress more reflective of the people.

\section{HISTORICAL ARGUMENT: ORIGINAL INTENT AND UNINTENDED OUTCOMES}

One of the most prevalent criticisms of the Electoral College is that it never truly functioned as intended and that its intent has been made archaic and obsolete by constitutional developments (Edwards, 2004; Levinson, 2003; Rakove, 2001). The general conclusion is that, due to developments that could not have been anticipated by the Framers of the Constitution-- developments that came about within the first generation of the American republic-- the Electoral College quickly became, and remains today, an anachronism (Chang, 2007, 208-209). In fact, one of the strongest proponents of retaining the Electoral College conceded that it "was unquestionably intended to serve ends we no longer care to serve, and which it no longer serves. Only in form does it remain what it was invented to be" (Bickel, 1971, 4).

The two interconnected developments that have occasioned such concern are the development of the twoparty system and the subsequent direct (popular) selection of electors. Criticisms based on these contentions cannot be easily dismissed. The Framers neither wanted nor intended a two-party system, and criticized its emergence as a decline into factionalism (Jillison, 1988, 40-42). They would have been further shocked to see a time when electors were identified on election ballots as supporters of particular parties (or not mentioned at all) and would, in effect, become rubber stamps for the will and purposes of the political parties. This was in clear conflict with the Framer's desire to see dispassionate, qualified individuals join together to debate and choose the most qualified candidate for the presidency. The question is whether such an obvious departure from these two aspects of intent indicates that the Electoral College fails to fulfill its original purposes and goals. The answer depends on how tightly drawn one's view of intent is.

A candidate who wins the Electoral College must craft a constitutional rather than a popular majority. By needing a majority of votes in the Electoral College, a successful candidate must obtain a plurality of the popular vote in each one of a group of disparate states that-together-provide the necessary electoral votes (Kuroda, 1994, 172). Rarely, as it turns out, can this be achieved by a candidate who fails to win a popular plurality within a significant number, if not a majority, of the states. Ironically, the Electoral College succeeds in fulfilling one of the broader "intents of the framers" through a development that the Framers could not foresee and did not desire: the two-party system (Bickel, 1971, 21-29). The development of the two-party system within the framework of the Electoral College has proved to be protective against factions and regional parties, a core concern of the Framers as a whole and James Madison in particular. His opening lines in Federalist 10 indicate approval for any plan or mechanism that can counter and control this phenomenon.

\begin{abstract}
'Among the numerous advantages promised by a wellconstructed Union, none deserves to be more accurately developed than its tendency to break and control the violence of faction. The friend of popular governments never finds himself so much alarmed for their character and fate as when he contemplates their propensity to this dangerous vice. He will not fail, therefore, to set a due value on any plan which, without violating the principles to which he is attached, provides a proper cure for it (Hamilton, Madison \& Jay, 1961)'.
\end{abstract}

Madison's extended republic has become a nation of remarkable breadth and diversity, and has provided a moderating impulse that political parties cannot ignore. In clear contrast with European Parliamentary democracies, the extended American republic, coupled with the evolution of the two-party system, has forced parties and candidates to seek broad, moderate, coalitions in order to win elective office (Raye, 2001, 63). In order to appeal to interests across the nation, presidential candidates and the parties they represent must "move to the middle," aggregate interests and make their appeal to a host of different concerns. Parties and their nominees must seek and achieve a national consensus in order to win political office. As a result, a winning coalition must attract and secure the votes of an identifiable majority of the electorate.

What brought this about? In part, a provision within Article II of the Constitution (and carried forward almost word for word into the $12^{\text {th }}$ Amendment), which specified the requirement for electoral victory. The language of the $12^{\text {th }}$ Amendment reads:

'The person having the greatest number of votes for President, shall be thePresident, if such a number be a majority of the whole number of electors Appointed [emphasis added] (Constitution of the United States, Amendment 12, Ratified September 25, 1804)'.

The majority requirement of both the original text of Article II and the modified language of the $12^{\text {th }}$ Amendment have virtually ensured one of the following adaptations or some combination of: 1) many competitive parties and a high likelihood that presidential elections will be decided in the House of Representatives; 2) many parties in a system dominated by one powerful party that regularly captures the majority of electoral votes (and where the minor parties scramble for the rest); or 3) multiple interests and groups coalescing into the bare democratic minimum: two competitive parties that each seek to build national coalitions by including as many groups and regional voting blocs as possible.

Many critiques of the Electoral College have centered on its undemocratic nature (See Anderson, 2005; Bennett, 2006, 
in addition to those already cited). Yet, each of the first two options mentioned above contain elements that are far less democratic than the current electoral system. The two-party system, developed around the majority requirement provision of Electoral College selection, which has led to a positive, though unanticipated, result (O'Sullivan, 1992). An electoral system that was intended to distance and insulate executive selection from popular impulse, coupled with the emergence of the much-feared party factions, led to a system that provides one of the most democratic possible outcomes in the greatest majority of cases. This system, functioning and competing within the stipulations of the Electoral College, virtually eliminates selection by the House of Representatives and assures that the eventual winner will be elected by a majority or near majority of the people. These outcomes cannot and should not be overlooked or dismissed. It can be argued that he two-party system is thus an extraconstitutional adaptation to the Article II/ $12^{\text {th }}$ Amendment majority vote requirement that mitigates the most undemocratic elements of the presidential selection process: a multi-candidate campaign that necessitates final selection in the House. At the same time, it also provides one of the strongest arguments against abolition of the Electoral College and a move to direct elections, in that it protects the election from producing a true minority president elected by a small plurality from a multi-candidate field. If an electoral system can be considered more "democratic" when it provides the best chance that the eventual winner will be the choice of the majority-or the closest possible percentage to a majority - the Electoral College framework, in conjunction with the two-party system, passes the test. ${ }^{3}$ Was this the framer's intent? In certain respects, no. Yet, it can be noted that, by the time the $12^{\text {th }}$ Amendment was proposed and ratified in the first few years of the $19^{\text {th }}$ Century, its framers had recognized these transformations and had adapted to them (Kuroda, 1994, 172). Not only did the Amendment change the voting procedure for Electors to avoid a repeat of the deadlocked election of 1800 , but it also accommodated the fact that party tickets and pledged electors had become part of the electoral process and were likely to become the norm (Busch, 2001, 27-42).

The need to obtain a constitutional rather than a strictly numerical majority through the Electoral College achieves, albeit inadvertently, an important aspect of the Framer's (and in particular, Madison's) intent. Regional parties, and factions with the ability to emerge as parties, are checked by the requirement of needing a broad, national plurality in order to prevail (Stoner, 2001, 50-51). It should also be noted that the biggest electoral vote prizes - the big statestend to be the most heterogeneous. They contain larger concentrations of minority voters, whether racial, ethnic, religious, or lifestyle, than the smaller states. A candidate or party hoping to have broad, national appeal must have a

\footnotetext{
${ }^{3}$ This author realizes that such a conclusion will not, and cannot, convince a reader whose definition of democracy assumes a steady historical, societal and doctrinal progression toward popular democracy over time. If pure popular democracy is the sole legitimate system for presidential selection, legitimacy cannot be granted to a definition of democracy based on majority rule with minority rights, or with a system that honors the accumulation of popular will within the states. At some point, however, consistency demands that other "undemocratic" aspects of the American polity - the composition of the Senate, the rules for amendments, and even the guaranteed one of representative per state in the House-must receive equal scrutiny. See the section that follows for a further discussion of this claim.
}

more moderate message in order to win the requisite number of big states.

After 200-plus years of American constitutional development, it can be asked whether the framers, looking upon the current system, would be satisfied that it serves a protective, constitutional function. For both the reasons stated above and the ones that follow, the strong possibility is that the answer would be yes (See especially Ross, 2004, 54-76).

\section{STRUCTURAL ARGUMENT: THE CRITIQUE AND DEFENSE OF FEDERALISM}

Close to one year after the announcement of Bush v. Gore and the official end of weeks of partisan brawling over the Florida vote, a Washington Post Weekly article appeared with the following title: "The 2000 Outcome: Blame Federalism" Harvard University professor John Mark Hansen explained that the "real source of Bush's victory" was neither the ability to outmaneuver the Gore camp in Florida in the month following the election, nor the "winnertake-all" system that awarded all of a state's electoral votes to the winner of the popular vote, but the institution of federalism (Hansen, 2001, 27). The strong federalist bias of the electoral system, Hansen argued, should be the main impetus for electoral reform. Somehow, democracy, fundamental fairness, and "one person, one vote" lost in the 2000 election. But who, or what, won? The Washington Post article concluded by pointing the finger squarely at the federal structure of our government and electoral system for choosing presidents.; "The key issue for the country is not just the sovereignty of the popular vote, an important consideration in itself. It is also the extent and limits of American federalism, and whether a system that gives major advantages to citizens of small states in Congress should also give a special advantage to small states in the vote for president" (Ibid., See also Haider-Markel et. al., 2002 and Wayne, 2003).

Is the Electoral College a vital and necessary component of American federalism? More to the point, is the federal principle worth defending and preserving if an aspect of that principle can lead to "undemocratic" results? Can an arrangement like the Electoral College be squared with an evolving understanding of American democracy?

If federalism is the problem, then the entire structure of American government is in need of reform. (Levinson, 2003, is one of the few constitutional scholars to make such a bold claim.) A perusal of the constitutional text and attention to the overall structure of the document and the relationships that emerge from it reinforces the federal principle, and also points us to a host of seemingly undemocratic institutions and procedures (Black, 1969). If democracy is defined as the committing of all decisions to the majority of the people (or, at the very least, to persons elected by the people and forced

\footnotetext{
${ }^{4}$ This paper does not attempt to tackle the question of bias within the Electoral College. It is fascinating to note though, that bias is identified as favoring both the small and the large states. While large states sport much larger electoral prizes (and thus gain the attention of the candidates and the media), small states benefit from the minimums required by the Constitution: at least one representative per state and the addition of two electoral votes reflecting representation in the Senate. While critics of both small state advantages (Hansen, 2001) and large state advantages (Wayne, 2003) can be identified, some observers have concluded that this results in what can be termed as an odd "countervailing bias" that creates advantages for each group of states.
} 
to seek frequent reelection), we are confronted with the fact that the American constitutional system of government in its entirety is radically undemocratic (Black, 1963).

A number of legal and political "givens" bear this out. In a 1997 testimony before a House Judiciary subcommittee, Professor Judith Best stated,

'If the Federal principle is illegitimate in Presidential elections, why isn't it illegitimate for the Senate? If numbers of votes are all that matters, why should a State with half a million people have the same representation as a State with 20 million people? And why should each State, regardless of its size, have at least one Representative in the House? Why shouldn't small States have to share a Representative with people from another State? And why should each State have an equal vote on constitutional amendments? The attack on the Federal principle in Presidential elections is an attack on that principle in the whole Constitution (Committee on the Judiciary, US House of Representatives, Comments of Professor Judith Best, 1997, 24)'.

This argument can be extended further by examining congressional procedure in addition to congressional composition. In theory, a clear majority in the Senate can be produced by the votes of the Senators representing about $17 \%$ of the population. An overwhelming majority of the Senate can be produced by the votes of Senators representing less than half the country's population. When we recognize that some of the most important tasks of the United States Senate, such as the ratification of treaties and the impeachment of officers, require a two-thirds majority, the seemingly undemocratic nature of the Senate stands out in even more bold relief.

This could be taken further still. No one has advanced the idea that we should add up the number of votes that all of the Democratic and Republican Senate candidates receive in an election and compare the totals. Should one party be the "majority" party in the Senate if the aggregate votes for that party exceed the votes for the other party, even if the latter party holds more Senate seats? With so much riding on achieving a majority in the Senate (witness the tidal change of power when Vermont Senator Jim Jeffords left the Republican Party and broke the 50-50 deadlock after the 2000 elections and the subsequent effect upon judicial nominees and confirmation hearings), any part of the process perceived to be "undemocratic" could become suspect.

The same point could be made about a number of other constitutional provisions (some less clearly tied to the federal principle) that we take for granted. The Bill of Rights becomes pointedly undemocratic if we hold to the aforementioned definition of democracy. If it can be assumed that Congress will make laws that the majority finds acceptable and desirable, one must confront the first five words of the First Amendment, Congress shall make no law. The only possible reason for such a prohibition is to forbid laws which the elected representatives of the people have passed. It ca be concluded that if the Bill of Rights does not restrain the temporary will of the majority, then it does not operate at all.

The foundation of our rights and liberties and the functioning of many of the constitutional checks and balances all seem to thwart the will of the majority, in much the same fashion as the Electoral College may do when the popular vote winner is not awarded the majority of the electoral votes. One of two things must happen. Either our constitutional structure must be called into question or our definition of democracy must be re-examined. Professor Best addressed this difficulty in her House testimony in 1997.

'Under the federal principle successful candidates must have consensus building skills. The goal of politics in this country is harmony-majority rule with minority consent. But when and why would a minority consent to majority rule? The answer is only if the minority can see that on some occasions and on some vital issues it can be part of the majority. It is irrational to consent to a game in which you can never win anything at all. To gain minority consent the Framers created many devices to allow minorities to be part of the majority, devices that gave minorities more influence than their raw numbers would warrant including the state equality principle for representation in the Senate and the state distracting principle in the House of Representatives. (The majority party in the House is often "over-represented" if our measure is raw numbers of votes nationally aggregated.) Then, of course, there is the state equality principle in voting on constitutional amendments. And there is the three-fourths requirement for passage of amendments. Such devices are designed to give minorities an influential voice in defining the national interest. The president is a major player in defining the national interest, and therefore it is necessary that the presidency be subjected to the moderating influence of a federal election system [emphasis in original] (Committee on the Judiciary, US House of Representatives, Comments of Professor Judith Best, 1997, 26)'.

When we locate democracy in this way, we end up with a definition that, while somewhat more complex than the will of the majority at all times and in all situations, is still able to operate within the constitutional structure and with the federal principle. The problem with the simple definition-an insistence on "one person, one vote" in all instances and at all times-- is that it allows for inconsistent consequences. The majority can always act in such ways (individually, in groups, or through their elected representatives) toward those who are not in the majority to undercut the legitimacy of democracy itself. In short, the majority can oppress the minority. The constitutional mechanisms that check the power of the majority may, in effect, act more to preserve democracy than to contradict it. Without such checks, democracy could defeat the very values on which it is based (Zakaria, 2001).

If the Electoral College can be defended with such a conception of democracy, it can also be carried along by the same arguments - structural in nature-by which we can defend the Senate, the one state minimum in the House, and the process of amendment. The Electoral College is part of an overall system that protects democracy from the majority. It operates within a framework of government designed to check the ability of the majority.

Some scholars, however, have sought to de-link the structure and form of the Electoral College from its purpose. Longley and Braun address those who contend that, 
"...abolition of the electoral college would seriously injure or even bring about the destruction of American federalism. The assumption here is that the present apportionment of electoral votes according to a state's representation in Congress embodies the federal compromise, and therefore, is an integral part of the federal system of government" (Longley \& Braun, 1975, 83-84).

For these writers, while the Electoral College may resemble the key aspects of federalism, it does not serve a similar purpose. Citing Senator Birch Bayh, they agree that, "the Electoral College system is not a fundamental ingredient in the Federal system. It's more or less an accidental coincidental parallel" (Ibid., at 84). The office of the presidency, and the president himself, represents the people as a whole, not the states. The essence of federalism is "the very fact of state and local levels of government engaged in decision-making activities... not a constant two allocation of electoral votes" (Ibid.).

Longley and Braun make this argument to clear the way for direct popular vote of the president (See also Amar \& Amar, 2001 and the web site of National Popular Vote). They do not argue, as does Hansen, that federalism is the key problem. Instead, they contend that federalism is irrelevant to a critique of the Electoral College (Edwards, 2004; Peirce \& Longley, 1981). If we grant this point, does it clearly and definitively point the way to direct election? Do we solve the problems of the Electoral College and restore legitimacy to the electoral process? The following section addresses those questions.

\section{ETHICAL ARGUMENT: FINDING AND DEFENDING DEMOCRATIC LEGITIMACY}

Arguments based on intent and structure bind the interpreter close to the text. However, there are many times when constitutional decision-making bypasses text and intent, and relies more heavily on logical reasoning, the evolving needs of society and practical outcomes. In Constitutional Fate, one of the clearest expositions of the modes of constitutional argument, Phillip Bobbitt identifies less text-bound forms of interpretation as ethical argument. He explains,

'If you were to take a set of colored pencils, assign a separate color to each of kinds of arguments, and mark through passages in an opinion of the Supreme Court deciding a constitutional matter, you would probably have a multi-colored picture when you finished'...

'If you ever take up my suggestion and try this sport you will sometimes find... that there is nevertheless a patch of uncolored text. And you may also find that this patch contains expressions of considerable passion and conviction, not simply the idling of the judicial machinery that one sometimes finds in dictum...'

'The class of arguments that I will call ethical arguments reflects, like other constitutional arguments, a particular approach to constitutional adjudication (Bobbitt, 1982, 93-94)'.

Some of the strongest arguments in support of the Electoral College emerge from an examination of alternative outcomes and potential consequences. They are not grounded as much in the text as they are in logic and common sense.

Before moving to the main part of the discussion of legitimacy, one key, and intriguing, point needs to be made. Somewhere (a quick footnote will not suffice and this is as good a place as any), the question of the 2000 vote count must be addressed and clarified. Couched within the current Electoral College debate is the claim that George W. Bush's failure to win a plurality of the popular vote undermines his legitimacy as President. I would like to argue that the claim is meaningless, as each candidate in the 2000 elections sought to win electoral and not popular votes. The goalclearly understood by each candidate and their huge staffs of advisors and experts - was to win enough states to secure the mandatory 270 total and win the presidency (Shaw, 2006). All of the time, effort and money spent were geared toward this strategy, not gaining the majority of the popular vote. Given the remarkable closeness of the 2000 election, with less than four-tenths of a percentage point separating the two candidates, there is no way to determine who would have won the popular vote had the candidates shifted their efforts toward winning a simple national majority. ${ }^{5}$ Michael Meyerson has used the metaphor of American baseball's World Series to underscore this misreading of rules and outcomes. The World Series winner is not the team that scores the most runs, hits the most home runs, has the highest batting average or lowest earned run average (or can lay claim to all of those statistics), but the team that prevails in the most games (Meyerson, 2002, 58). Michael Herz concurs, "To win the World Series, a team must win four games. The winner always and by definition prevails in a majority of the games played. However, the winner does not necessarily score the most total runs. If it loses blowouts and wins squeakers, a team will win the Series despite scoring far fewer total runs" (Herz, 2002, 1193-1197).

Candidates have incentives to carry states and win their electoral prizes. Those are the rules that are known and accepted by each party in advance. In close elections where the electoral vote and the popular vote diverge, the popular vote can have no residual meaning that can be used to make a case that its winner was the true or legitimate winner of the election.

No matter how we ultimately decide upon a definition of democracy, American constitutional development has witnessed increasingly greater democratic access, enlargement of the franchise and, in one key area, the move from indirect to direct election of legislators (where the Seventeenth Amendment provides for popular election of Senators in the states). Levinson (2003) notes that, of the constitutional amendments beyond the original ten in the Bill of Rights, no fewer than nine (out of 15 still in force) helped to address the Constitution's democratic defects, with five of those nine specifically enhancing voting rights. There remains an elegant simplicity to the contention that the Electoral College "undemocratically separates people from the presidential election process" (O’Sullivan, 1992, 2421) and that "fairness dictates that the electoral college should be

\footnotetext{
The total vote count in the election was 51 million for Gore and 50.5 million for Bush. Another way to illustrate the closeness of the 2000 election is that if there had been swing of eight votes to Bush in each of the nation's voting precincts, Bush would have won the popular vote.
} 
abolished" (Gringer, 2008, 223). Public opinion polls regularly show support for the idea that direct popular election of the president will "solve" the problem of the Electoral College and restore democratic principles to the electoral process. ${ }^{6}$ Unfortunately, there are both pitfalls around and unintended consequences to the direct election plan that may do more harm that good to our conceptions of democracy and "one person, one vote." This study has already addressed the claim that the 2000 election results were "undemocratic" on the grounds that the winner of the popular vote lost the election. For now, let us assume that candidate Al Gore would have won the popular vote no matter what campaign strategy the candidates had used. Given the outcome of the 2000 presidential elections, would this provide a more compelling argument for direct popular election - if the primary desire is to restore and ensure a democratic outcome?

An earlier section of this study contended that the twoparty system was a necessary and inevitable outgrowth of the Constitution's majority requirement for presidential elections. One consequence of a constitutional amendment that would abolish the Electoral College and institute direct elections of presidents would be the undermining, and probable end of the two-party system. While some scholars have determined that the dissolution of the two-party system is an acceptable price to pay for the assurance of a more popularly democratic electoral outcome (i.e., the assurance that the winner of the popular vote would win the election), there would be a number of consequences with which to deal. Most, if not all, would be injurious to the larger democratic forms and processes that are part of the present system.

Direct election of the president would not solve the problem of democracy-defined-as-majority rule. In fact, it would shift the problem to a different aspect of the electoral process. Proponents of direct election recognize that abolishing the Electoral College in favor of direct election would virtually guarantee that no one candidate would receive $50 \%$ of the popular vote. The majority electoral vote provision would be eliminated, and with it, the tendency for groups and interests to cluster into the democratic minimum of two parties. As a result, most calls for direct election provide for some kind of runoff election in the event that no candidate clears the $50 \%$ threshold, or concede that a lower threshold of victory may be a necessary compromise.

The majority electoral vote requirement of the $12^{\text {th }}$ Amendment does not eliminate third parties, but it has had the tendency to suppress their power and scope in the national electoral process. Typically, third parties have either been able to attract a regional following and win the electoral votes within a tight geographical concentration (George Wallace in 1968) or have uniform minority appeal across the nation without gaining any electoral votes (Ross Perot in

\footnotetext{
${ }^{6}$ This essay does not address other proposals for reform of the Electoral College, such as the district plan, where state legislatures create single-elector districts equal to the number of Representatives from that state. The candidate who wins a plurality of the popular vote in the district would receive the vote of that elector. The candidate with a plurality of the state-wide vote would win the two electoral votes representing the state's two Senators. Critics claim that this plan, currently used in both Maine and Nebraska, could still result in electing a President who comes in second in the national vote. The bias of federalism would be lessened, but not eliminated. Discussions of these alternative proposals can be seen in Longley and Peirce (1999), Peirce and Longley (1981), Yunker and Longley (1976), and Zeidenstein (1973).
}

1992). One of the "protective" qualities of the Electoral College has been its ability to keep regional, and in most cases extreme, candidates from winning a plurality of the vote and with that, the presidency. As discussed earlier, this is enhanced by the greater heterogeneity of the larger states, without which it would be impossible to win an election. ${ }^{7}$ This has not taken away the potential for a regional third party candidate to gather enough electoral votes to push an election into the House of Representatives and then become a deal-maker who can bargain with the leading candidates for concessions in order to win the House vote (Bennett, 2006, 74-85). The closest this came to happening was 1824 . Under a direct election plan where there would be a national runoff if no candidate received $50 \%$ of the vote, a two-phase electoral system would likely become standard. This would turn the general election into a national primary. It would encourage third parties to create a power base and use to it help determine the outcome of runoff elections. Third party leaders could become power brokers in runoff elections, exacting promises over policy issues, funding for programs, or judicial appointments in return for an endorsement. The kinds of impulses that give rise to fringe parties or manifest themselves within interest groups: single-issues, ideological extremes and a host of ethnic, class or racial identity platforms, could develop into competitive parties under the new rules for electoral victory (Moynihan, 2001, 87-88)..

Direct elections would also have a profound effect upon the timing of elections. Runoff elections would push the electoral process out by weeks, if not months, as the finalists gear up for the final election. More worrisome would be the probability that recounts would become standard for most every close election. Not only would close runoff elections spark recounts nationwide, but the general election would potentially face the problem of determining which candidate obtained sufficient votes to qualify for a runoff election. One of the strongest arguments for the Electoral College system and the federal principle on which it rests is that the system compartmentalizes and limits crisis. The autumn 2000 partisan struggle in Florida, still clear in minds of a bewildered voting public, could become the norm across the country. Richard Posner, whose book argues against the current Electoral College format, still recognizes the pitfalls of vote challenges and call for recounts if elections are freed from the state unit rule.

'The last advantage of retention is highlighted by the 2000 election. Were Presidents elected by popular vote, a nationwide recount might have been unavoidable in 2000 (and in a number of previous Presidential elections as well, such as those in 1876, 1880, 1884, 1888, 1960, 1968 , and 1976, in all of which the popular vote was very close) because Gore's popular vote margin was so slight. He received 51 million votes and Bush 50.5 million, a difference of 0.5 percent. If a plurality of the popular vote were what elected a President, a margin this small would have incited calls for a national recount on the same grounds that Gore argued for a Florida recount. Even though under a post-Electoral College, pure popular vote regime the Presidential election would presumably

\footnotetext{
${ }^{7}$ At present, the largest 12 states award 271 electoral votes, 2 votes more than half of the total number (538) and 1 more than what is needed to secure victory. The other 38 states award 267 electoral votes.
} 
still be administered by the states, no state could refuse the demand for a recount on the ground that the election in that state had not been close. The state would no longer be a relevant entity for purposes of determining the winner of the election. Each candidate would be trolling for votes everywhere across the country (Posner, 2001, 233-234)'.

Extremely close elections, like that of 2000, would likely create nation-wide controversy, rancor and accusations from all concerned parties (Hardaway, 1994, 158-160). The strength of the current system is that it localizes a deadlock to either one or possibly a few states. If a candidate wins California by a million votes within the present electoral system, California's result is easily recognized and not subject to dispute. However, if that same candidate wins California by a million votes but only wins the national election by a few thousand votes (under a pure popular election system), all of California's votes are fair game for legal challenge and mandatory recounts. The federal principle, on which the Electoral College is based, protects against such a possibility.

The Electoral College has successfully made the general election the only election. In addition to requiring that the winning candidate have national approval and national appeal, most elections since 1824 have provided a swift and certain conclusion and have taken away the potential for fraud, back room deals and corruption (Best, 1975, 191-204 and Best 1996). The one glaring exception to this record, the election of 1876 , serves as a warning to what can happen when the selection of the president becomes a process of political maneuvering, regional bargaining and outright fraud. With the repeal of the Electoral College system the machinations surrounding the Florida recounts in November and December of 2000 could easily become the norm every four years.

\section{CONCLUSION}

The legitimacy of the Electoral College has been called into question because it does not perfectly confirm the will of the majority and does not perfectly reflect the concept of "one person, one vote." It cannot be denied that federal principle does exert a limitation on this view of democracy and democratization, as the popular will is measured on a state-by-state rather than a national basis. Yet, the benefits of the Electoral College system over time have far outweighed its shortcomings.

Does the Electoral College remain a "constitutional" system for electing the President? If it is placed within a definition of democracy that sometimes tempers the will of the majority, the answer is yes. If it enables the electoral process to avoid the worst expressions of contested elections, recounts, uncertain outcomes and fringe party presidents, the answer is yes. And when the Electoral College is located within a constitutional structure that continues to reflect Madison's compound ratio of popular impulse expressed through state units, the answer is yes.

In 1970, when Charles Black testified before the Senate Committee on the Judiciary, he warned that any change to the structure of the Constitution was "to be approached with every presumption against it." Black asserted that abolishing the Electoral College in favor of direct elections could do irreparable harm to the political system. In making his points, he pointed to the federal system as a continued source of the Constitution's strength and durability, and he concluded that elimination of the Electoral College would subvert that system. He warned that the amendment under consideration (to abolish the Electoral College in favor of direct elections) would be "the most deeply radical amendment" that could be added to the Constitution (Committee on the Judiciary, US Senate, Testimony of Charles L. Black).

As we look back upon the 2000 and 2004 elections and look forward to the American presidential election in 2008, we would do well to consider Professor Black's words.

\section{BIBLIOGRAPHY}

Amar, A. \& Amar, V. (2004) Why Old and New Arguments for the Electoral College are Not Compelling. In J. Fortier (Ed.), After the People Vote: A Guide to the Electoral College, (Chapter 10). Washington, DC: AEI Press.

Amar, A. \& Amar, V. (2001) How to Achieve Direct National Election of the President Without Amending the Constitution. FINDLAW. December 28. Retrieved June 5, 2008 from: http://writ.news.findlaw.com/amar/20011228.html.

Anderson, J. (2005) The Electoral College Flunks the Test in an Age of Democracy. Human Rights: Journal of the Section of Individual Rights \& Responsibilities, 32(2), Spring. 17-19.

Bennett, R. (2006) Taming the Electoral College. Stanford: Stanford University Press.

Best, J. (1996) The Choice of the People: Debating the Electoral College. New York: Rowman and Littlefield.

Best, J. (1975) The Case Against Direct Election of the President: A Defense of the Electoral College. Ithaca, NY: Cornell University Press.

Bickel, A. (1971) Reform and Continuity: The Electoral College, the Convention, and the Party System. New York: Harper and Row.

Black, C. (1969) Structure and Relationship in Constitutional Law. Baton Rouge: Louisiana State University Press.

Black, C. (1963) The Supreme Court and Democracy. In The Occasions of Justice, (Chapter 6). New York: Macmillan.

Bobbitt, P. (1982) Constitutional Fate: Theory of the Constitution. New York: Oxford University Press.

Busch, A. (2001) The Development and Democratization of the Electoral College. In G. Gregg (Ed.), Securing Democracy: Why We Have an Electoral College, (pp. 27-42). Wilmington, DE: ISI Books.

Chang, P. (2007) Updating the Electoral College: The National Popular Vote Legislation. Harvard Journal on Legislation, 44, 205-229.

Committee on the Judiciary, U.S. House of Representatives, One Hundred Fifth Congress, First Session, (1997) Proposals for Electoral College Reform. Comments of Professor Judith Best. September 4. On H.J. Res. 28 and H.J. Res. 43. Washington, DC: U.S. Government Printing Office.

Committee on the Judiciary, U.S. Senate, Ninety-First Congress, Second Session, (1970) Electoral College Reform: Hearings on Amending the Constitution Relating to Electoral College Reform. Testimony of Charles L. Black. April 15-17. Washington, DC: U.S. Government Printing Office. 191-247, 291-348.

Constitution of the United States. Retrieved May 9, 2008 from: http://www.usconstitution.net/const.html

Edwards, G. (2004) Why the Electoral College is Bad for America. New Haven: Yale University Press.

Fuentes-Rohwer, L. \& Uriel-Charles, G. (2001) The Electoral College, the Right to Vote, and Our Federalism: A Comment on a Lasting Institution. Florida State University Law Review, 29, 879-917.

Gringer, D. (2008) Why the National Popular Vote Plan is the Wrong Way to Abolish the Electoral College. Columbia Law Review, 108(1), $182-230$.

Haider-Markel, D., Dubnick, M., Elling, R., Niven, D., \& Schumaker, P. (2002) The Role of Federalism in Presidential Elections. In Schumaker, P. \& Loomis, B. Choosing a President: The Electoral College and Beyond, (Chapter 4). New York: Chatham House/ Seven Bridges Press. 53-73. 
Hansen, J. (2001) The 2000 Outcome: Blame Federalism. The Washington Post National Weekly Edition. 19(7), December 10-16.

Hardaway, R. (1994) The Electoral College and the Constitution: The Case for Preserving Federalism. Westport, CT: Praeger Press.

Herz, M. (2002) How the Electoral College Imitates the World Series. Cardozo Law Review, 23(4), 1191-1218.

Jillison, C. (1988) Constitution Making: Conflict and Consensus in the Federal Convention of 1787. New York: Agathon Press, Inc.

Kuroda, T. (1995) The Origins of the Twelfth Amendment: The Electoral College in the Early Republic, 1787-1804. Westport, CT: Greenwood Publishing.

Longley, L. \& Peirce, N. (1999) The Electoral College Primer 2000. New Haven: Yale University Press.

Longley, L. \& Braun, A. (1975) The Politics of Electoral College Reform. New Haven: Yale University Press.

Madison, J, Hamilton, A, and Jay, J. (1961) Federalist. New York: New American Library of World Literature.

Meyerson, M. (2002) Political Numeracy: Mathematical Perspectives on Our Chaotic Constitution. New York: W.W. Norton.

Moynihan, D. (2001) The Electoral College and the Uniqueness of America. In G. Gregg (Ed.) Securing Democracy: Why We Have an Electoral College, (pp. 87-102). Wilmington, DE: ISI Books.

National Popular Vote web site. Retrieved May 31, 2008 from: $\mathrm{http}: / /$ nationalpopularvote.com/npv/.

O'Sullivan, M. (1992) "Artificial Unit Voting and the Electoral College." Southern California Law Review, 65, 2421-2447.
Posner, R. (2001) Breaking the Deadlock: The 2000 Election, the Constitution, and the Courts. Princeton, NJ: Princeton University Press.

Peirce, N. \& Longley, L. (1981) The People's President: The Electoral College in American History and the Direct Vote Alternative. Revised Edition. New Haven: Yale University Press.

Rakove, J. (2001) The Unfinished Election of 2000. New York: Basic Books.

Raye, P. (2001) Moderating the Political Impulse. In G. Gregg (Ed.) Securing Democracy: Why We Have an Electoral College (pp. 5578). Wilmington, DE: ISI Books.

Roche, J. (1961) The Founding Fathers: A Reform Caucus in Action. American Political Science Review, 60, 799-816.

Ross, T. (2004) Enlightened Democracy: The Case for the Electoral College. Dallas, TX: Colonial Press.

Shaw, D. (2006) The Race to 270: The Electoral College and the Campaign Startegies of 200 and 2004. Chicago: University of Chicago Press.

Stoner, J. (2001) Federalism, the States, and the Electoral College. In G. Gregg (Ed.) Securing Democracy: Why We Have an Electoral College, (pp. 43-54). Wilmington, DE: ISI Books.

Wayne, S. (2003) Is This Any Way to Run a Democratic Election? $2^{\text {nd }}$ Edition. Boston: Houghton Mifflin Company.

Yunker, J. \& Longley, L. (1976). The Electoral College: Its Biases Newly Measured for the 1960s and 1970s. American Politics Series. Volume 3. Beverly Hills, CA: Sage Publications.

Zakaria, F. (2001) The Future of Freedom. New York: W.W. Norton.

Zeidenstein, H. (1973) Direct Election of the President. Lexington, MA: D.C. Heath and Company.

This is an open access article licensed under the terms of the Creative Commons Attribution Non-Commercial License (http://creativecommons.org/licenses/by-nc/3.0/) which permits unrestricted, non-commercial use, distribution and reproduction in any medium, provided the work is properly cited. 